\title{
Products and Services in Cyberspace
}

\author{
Joe Peppard, \\ Cranfield School of Management, \\ Cranfield, \\ Bedfordshire MK43 0AL \\ United Kingdom. \\ Phone: +44 1234754421 \\ Email: j.peppard@cranfield.ac.uk
}

Anna Rylander,

Royal Institute of Technology,

KTH Syd, Marinens väg 30,

13640 Haninge,

Sweden.

Phone: +46 87904829

e-mail: anna.rylander@syd.kth.se 


\title{
Products and Services in Cyberspace
}

\begin{abstract}
In the physical world, products and services are traditionally distinguished from each other on the basis of tangibility and intangibility; indeed, services are often described as intangible products. In the virtual world of the fixed and mobile Internet, however, this distinction is no longer appropriate: both products and services become intangible. This is essentially because the Internet is not merely a technology but represents an entirely new medium for conducting business, a fact that was overlooked by many of the early entrants into this space. This medium is defined by information and fundamentally different from the physical space where business has traditionally been transacted. Consequently, the concept of products and services requires study. In this paper we focus on business-to-consumer (B2C) markets and explore consumer products and services in cyberspace, distinguishing them along a number of dimensions.
\end{abstract}

\section{Keywords}

Internet, Online strategy, Information products, Physical information products, Digitally mediated services

\section{Introduction}

The commercialisation of the Internet has seen it being deployed for corporate communications, for facilitating trading activities, for distributing digital content, for the provision of a wide range of services, and as a platform for collaboration. While many organizations have migrated products and services from the physical world to the virtual world, or created new and innovative offerings to take advantage of the capabilities of the technology, lessons from these early forays clearly indicate that it is not an electronic replication of the physical world (Butler and Peppard, 1998; Evans and Wurster, 2000; Jarvenpaa and Grazioli, 2000). Indeed, more than a mere a technology, the Internet represents an entirely new medium for conducting business. Not only does it have different attributes than the physical world but within this virtual space much of what is taken for granted in dayto-day commercial activities and decision-making processes are absent. In B2C (business-toconsumer) markets, the focus of this paper, consumer behaviour is also different (Butler and Peppard, 1998).

In the physical world, products and services are generally distinguished from each other on the basis of tangibility - products are portrayed as tangible, i.e. can be touched, while services are seen as being intangible, i.e. cannot be touched (c.f. Slack et al., 2001). Services have been described as “intangible products” (Heizer and Render, 1999, p. 13) and are Pre-publication version International Journal of Information Management, Vol 25, 2005, pp. 335-345. 
generally not precisely defined, but defined based on what they are not rather than what they are (c.f. Schmenner, 1995). While many products today have a service component, or provisioning of a service has a physical aspect, with the advent of the Internet, both products and services become intangible. Couple this with the Internet as a medium and we are faced with an entirely new environment and set of circumstances not only for conducting business but also for managing operations. If companies are going to be successful with their online strategies analysis would suggest that it is crucial for them to understand the characteristics of goods and services in the virtual world as well as the behaviour of consumers when they move online (Butler and Peppard, 1998; Koufaris et al., 2002).

Indeed, the distinction between products and services has guided theory and practice in operations management. A recent study identified differences that related to measurements used to assess effectiveness and efficiency, differences in production strategies and differences in production process between organizations producing tangible goods and intangible services (Bowen and Ford, 2002). Whether there are any differences when operating in the virtual world has yet to be addressed in the literature. But before such a task can be undertaken it is necessary to understand this virtual world as well as the nature and behaviour of products and services in this environment. The objective of this paper is to explore products and services in cyberspace in order to develop a categorisation that is more appropriate in guiding management action.

The paper first investigates the Internet as media, drawing out a number of pertinent implications. It then examines some of the fundamental attributes of information products and digitally mediated services. A categorisation of the different types of digital content is developed and comparisons made across a number of dimensions. The paper concludes with some implications.

\section{The Internet as Media}

In "going on the net", what many organizations have failed to consider is that the Internet is an entirely new medium for conducting business and that the implications of this must be considered. This medium is an information-defined space. Apart for having no physical manifestation, its shape, look, topology and context are all defined by information. It also exhibits a number of distinct features that differentiate it from physical space. Issues of geography and location are no longer important for the production and distribution of information (Butler, 2003). It provides individuals and organizations with the capability to 
control the production, storage and dissemination of information (Havick, 2000). The constraints of space, all too present in the physical world, cease to be relevant. It is perhaps the absence of physical and tangible artefacts in this information-defined space that have the most serious implications for consumer behaviour. These artefacts provide the clues that are crucial for humans in their decision-making processes, and their absence has implications for trust, for building brands, and for establishing customer relationships.

For example, one of the principal reasons that many pure-play Internet banks failed was due to the lack of trust that existed between the online venture and customers. Confidentiality and security are key components of trust (Dayal et al., 2000; Kim and Prabhakar, 2000; Torkzadeh and Dhillon, 2002). In the physical world of banking, physical cues like large imposing branches and knowledge of the person managing your account all contribute to the creation of trust. On the Internet such cues are absent, which has resulted in people being reluctant to deposit their money with such virtual institutions. Contrast this with the relative success of on-line brokerages, where an "intelligent" customer base, trading process, and the dematerialization of the product over many years, made them more suited to new pure-play start-ups. Researchers in consumer behaviour have found that consumers recognise differences in size and reputations among Internet stores and that these influence their assessment of the store trustworthiness, their perception of risk, and their willingness to shop with a particular store (Koufaris and Hampton-Sosa, 2004; McKnight et al., 2002). A customer who believes that there is a physical store behind a website is more likely to trust the site on first encounter (Jarvenpaa and Grazioli, 2000).

Physical spaces form important constituent parts of what we might call "settings", to which a set of social norms instructing us how to behave are attached. For example, when a person enters a library (or an office, a theatre, a church...) he has never been in before, he generally recognises it as a library and behaves and interacts with other people accordingly (Lawson, 2001). Such norms of behaviour are still largely absent in the virtual world. On the flip side, the technology cannot interpret many of the clues, both verbal and non-verbal, given off by a human, as might occur in physical settings. Consider, for example, the reaction of a customer when he sees an unexpectedly high price for a piece of furniture. In the physical world the salesperson can adjust his approach, make another suggestion or offer a "better deal".

Nevertheless, people's interactions with computers and new media are fundamentally social and natural, i.e. we expect media to obey a wide range of social and natural rules. These rules are derived from the physical world of interpersonal interaction. Reeves and Nass Pre-publication version International Journal of Information Management, Vol 25, 2005, pp. 335-345. 
(1996) have conducted research on social responses to communication technologies for over 10 years and coined the term "the media equation", meaning media equals real life, to illustrate this relationship. The media equation is counterintuitive; we may know intellectually that computers do not have feelings, that a computer programme is neither friendly nor hostile, does not have a gender, that a ball thrown at us on a screen will not hit us and so forth, still we treat them as if they do. According to the media equation all humans automatically and unconsciously respond socially and naturally to media. The implications for developers of online products and services are numerous. For example, the same rules of politeness apply for web solutions as in real life, something often overseen by web-site developers. Furthermore, people will assign a personality to characters on a web site or possibly an entire solution, based a number of simple rules that we use in everyday life. Words and pictures in media are symbolic representations of "things" such as images, ideas and facts that are not actually present. When this information is mediated we often assume that people only think about who sent the information and why, and what it means. However, research shows that this view can assume too much - when a picture threatens, we don't think about who created it, what they intended and what it all means; we often think only about what we should do (Reeves and Nass 1996). Put simply, humans have not evolved to accommodate twentieth century technology. The human brain evolved in a world in which only humans exhibited rich social behaviour, and a world in which all perceived objects were physical objects - anything that seemed to be a 'real' person or place was 'real'.

The media equation is particularly relevant for information mediated via the Internet as the Internet is an interactive space permitting two-way communication, something that was not possible with older technologies such as electronic data interchange (EDI). This creates an environment of immediacy and presence - just consider the impact of instant messaging (IM). The Internet defines a new communications environment, what Castells (2001) refers to as "the Internet Galaxy" with its own logic and its own language. Profoundly, he notes that with the Internet, communication is usually embedded in social practice, "not isolated in some kind of imaginary world." And because communication is the essence of human activity, all domains of social life are being modified by the pervasive uses of the Internet.

It is within this medium that organizations are increasingly operating. While the strategic implications of the Internet have been addressed (Evans and Wurster, 2000; Porter, 2001; Sampler, 1998) the nature of products and services in this medium issues have not received the same treatment. For example, the operations function is traditionally responsible for 
producing and delivering products and services, however guidance and best practice are premised on activities existing in the physical world, with the distinction between products and services guiding decision making. In the remainder of the paper we explore products and services in cyberspace.

\section{The Concept of Products and Services in Cyberspace}

Products and services made available using the Internet will be defined and shaped by information. This information can be information already available in the organization (e.g. pricing or product availability) or new information, whether created within the organization itself (e.g. richer descriptions of products or digitization of services) or imported from an external source (e.g. complementary information that can be integrated with internal information to create a new offering or information provided by a customer to co-create a product).

Information products are products that may currently exist in a physical form, but can be digitised and distributed electronically. Included are text, images, sounds, video, software, etc. Such products are essentially knowledge that has been made explicit and turned into information that has been formalised, for example, books, newspapers, music, a baseball score, stock prices or a web site. They may also represent the intellectual endeavours of the staff of an organization, such as with research, where new knowledge, created within an organization, is offered for sale. Information products can also be information assets that have been packaged to appeal to a certain audience or market, for example stock prices for private investors.

Apart from innovative services (see below), some traditional services are also mediated by the new medium - what we refer to as digitally mediated services. This continues the evolution that has been occurring in service industries as organizations attempt to automate aspects of the service delivery process to reduce cost and increase quality and consistency of the service as well as improve both convenience and availability of the service (Quinn et al., 1990). Many online services are information-mediated versions of services that exist off-line. Amazon.com provides a book purchasing service. Expedia.com is an online travel agent. Tesco.com is an online grocer. However, books purchased on Amazon.com or Barnsandnoble.com are delivered to the customer by courier or post (although e-books can be distributed electronically). These sites provide the mechanisms to bring together buyers and sellers and then transact business; it is this process that is mediated by an information-defined 
environment. Online banks provide customers with services on-line that allows them, among other things, to undertake transactions and check balances via the Internet.

The Internet also supports innovative service designs. For example, Salesforce.com delivers sales force automation (SFA) functionality over the Net. For a monthly fee, small and medium sized firms in particular, can avail of functionality that would probably be prohibitively expensive for them using tradition delivery mechanisms. Person-to-person auctions such as eBay.com, or spread-betting operations like Betaq.com, are not commercially viable in the physical world. Location-based services look set to be a key offering for mobile devices. In Tokyo, for example, J-Phone's J-Navi service lets users enter a phone number, address or landmark, and then searches the area within 500 meters. This makes it possible to find the subway station nearest to a particular shop, or a particular kind of restaurant within walking distance of a particular office building; a map to these locations can also be provided.

Both digital information products and digitally mediated services have increased in importance over the last few years and are set to do so even more in the future. However, there is a gap in the theory addressing the development, management and marketing of such products and services. Digital offerings are neither pure products, nor pure services in the strict meaning of the terms. They constitute a category of their own as they have a different set of characteristics and therefore need to be managed accordingly. In addition, appropriating value from digital information products and digitally mediated services demands different strategies than in the physical world.

\section{Information Products, Digital Information Products and Digitally Mediated Services}

Table 1 compares products and services in the physical and virtual worlds across a number of dimensions. Grönroos (1990) has summarised the most commonly mentioned characteristics of services and physical products found in the literature and we have used these in our analysis. We have added two additional categories of information products to the table to illustrate the differences between physical and digital information products. By traditional information products we include those with a physical dimensions, for example books, CDs or research reports available in the form of a physical document. With digital information products, content has been digitised and thus can be sold and distributed on-line. Examples 
are electronic books, music in the form of MP3 files, news, games, software, or the research reports sold on-line by companies.

Note, however, that today there are few "pure" products or services as companies selling products often try to enhance the value of their products by offering add-on services, and companies selling service often try to "productify" their services to make the value to the customer more concrete. This trend is illustrated by the rise of "solutions" as an attempt to profile a complex mix of physical product(s), service(s) and information product(s). Many physical products today often include an information product as a "wrap around" to enhance the solution to customers. For example, Slendertone, with its FLEX MAX toning product that exercises the muscles of the abdomen, offers a mentor service - an on-line personalised motivational and advice programme designed to help users of their products achieve diet and fitness goals (www.slendertone.com). With traditional and digital information products, the same content can be found in both physical and digital form. The purpose of Table 1, however, is to illustrate the differences between the different categories of offerings.

\begin{tabular}{|c|c|c|c|c|c|}
\hline Attributes & Physical products & $\begin{array}{l}\text { Services } \\
\text { provided in } \\
\text { physical world }\end{array}$ & $\begin{array}{l}\text { Physical } \\
\text { information } \\
\text { products }\end{array}$ & $\begin{array}{l}\text { Digital } \\
\text { information } \\
\text { products }\end{array}$ & $\begin{array}{l}\text { Digitally mediated } \\
\text { services }\end{array}$ \\
\hline $\begin{array}{l}\text { Level of } \\
\text { abstraction }\end{array}$ & Concrete & Abstract & Concrete & $\begin{array}{l}\text { Both a concrete } \\
\text { and abstract } \\
\text { dimension. }\end{array}$ & $\begin{array}{l}\text { Abstract, but with } \\
\text { a concrete } \\
\text { dimension because } \\
\text { of representation } \\
\text { in medium }\end{array}$ \\
\hline $\begin{array}{l}\text { Level of } \\
\text { heterogeneity }\end{array}$ & $\begin{array}{l}\text { Homogenous (all } \\
\text { products the same) }\end{array}$ & $\begin{array}{l}\text { Heterogeneous (all } \\
\text { services unique) }\end{array}$ & Homogenous & $\begin{array}{l}\text { Depends on the } \\
\text { level of } \\
\text { interactivity and } \\
\text { personalisation }\end{array}$ & $\begin{array}{l}\text { Can be both, } \\
\text { depending on level } \\
\text { of interactivity and } \\
\text { sophistication }\end{array}$ \\
\hline $\begin{array}{l}\text { Complexity of } \\
\text { value chain }\end{array}$ & $\begin{array}{l}\text { Production and } \\
\text { distribution } \\
\text { separated from } \\
\text { consumption }\end{array}$ & $\begin{array}{l}\text { Production, } \\
\text { distribution and } \\
\text { consumption are } \\
\text { parallel processes }\end{array}$ & $\begin{array}{l}\text { Production and } \\
\text { distribution } \\
\text { separated from } \\
\text { consumption }\end{array}$ & $\begin{array}{l}\text { Combination. A } \\
\text { digital information } \\
\text { product is to some } \\
\text { extent separated } \\
\text { from production, } \\
\text { but the final output } \\
\text { will sometimes be } \\
\text { co-created with the } \\
\text { consumer (in the } \\
\text { case of interactive } \\
\text { products). } \\
\text { Distribution can be } \\
\text { either separate or } \\
\text { simultaneous with } \\
\text { consumption }\end{array}$ & $\begin{array}{l}\text { Production is at } \\
\text { least partly } \\
\text { separate from } \\
\text { consumption - and } \\
\text { can be entirely } \\
\text { separate } \\
\text { (depending on } \\
\text { level of } \\
\text { interactivity). } \\
\text { Distribution and } \\
\text { consumption are } \\
\text { parallel processes. }\end{array}$ \\
\hline Object or process & An object & $\begin{array}{l}\text { An activity or } \\
\text { process }\end{array}$ & An object & $\begin{array}{l}\text { Combination. Can } \\
\text { be an object, but } \\
\text { predominantly a } \\
\text { process }\end{array}$ & $\begin{array}{l}\text { An activity or } \\
\text { process. }\end{array}$ \\
\hline
\end{tabular}

TABLE 1. Differences between physical and digital products, services and information products. 


\begin{tabular}{|c|c|c|c|c|c|}
\hline Attributes & Physical products & $\begin{array}{l}\text { Services } \\
\text { provided in } \\
\text { physical world }\end{array}$ & $\begin{array}{l}\text { Physical } \\
\text { information } \\
\text { products }\end{array}$ & $\begin{array}{l}\text { Digital } \\
\text { information } \\
\text { products }\end{array}$ & $\begin{array}{l}\text { Digitally mediated } \\
\text { services }\end{array}$ \\
\hline $\begin{array}{l}\text { Point of value } \\
\text { creation }\end{array}$ & $\begin{array}{l}\text { Real value }{ }^{*} \text { is } \\
\text { created during } \\
\text { production }\end{array}$ & $\begin{array}{l}\text { Real value is } \\
\text { created in the } \\
\text { interaction } \\
\text { between buyer and } \\
\text { seller }\end{array}$ & $\begin{array}{l}\text { Real value is } \\
\text { created during } \\
\text { production }\end{array}$ & $\begin{array}{l}\text { Real value is } \\
\text { created partly } \\
\text { during production, } \\
\text { partly on } \\
\text { consumption } \\
\text { (experience) - i.e. } \\
\text { in the interaction } \\
\text { between the } \\
\text { product and the } \\
\text { consumer }\end{array}$ & $\begin{array}{l}\text { Real value is } \\
\text { created partly } \\
\text { during production, } \\
\text { partly on } \\
\text { consumption } \\
\text { (experience) - i.e. } \\
\text { in the interaction } \\
\text { between the } \\
\text { service and the } \\
\text { consumer }\end{array}$ \\
\hline $\begin{array}{l}\text { Role of customer } \\
\text { in production }\end{array}$ & $\begin{array}{l}\text { Customer does not } \\
\text { (normally) take } \\
\text { part in production. } \\
\text { [If a product is } \\
\text { customised it is } \\
\text { more of a service] }\end{array}$ & $\begin{array}{l}\text { Customer is part } \\
\text { of production } \\
\text { process }\end{array}$ & $\begin{array}{l}\text { Customer does not } \\
\text { (normally) take } \\
\text { part in production }\end{array}$ & $\begin{array}{l}\text { Customer may or } \\
\text { may not be part of } \\
\text { the production } \\
\text { process, depending } \\
\text { on the level of } \\
\text { interactivity }\end{array}$ & $\begin{array}{l}\text { Customer may or } \\
\text { may not be part of } \\
\text { the production } \\
\text { process, depending } \\
\text { on the level of } \\
\text { interactivity }\end{array}$ \\
\hline Ability to store & Can be stored & Cannot be stored & Can be stored & $\begin{array}{l}\text { The "base” } \\
\text { product (e.g. } \\
\text { software) can be } \\
\text { stored, but not the } \\
\text { "end" product } \\
\text { (experience), } \\
\text { particularly if } \\
\text { interactive. }\end{array}$ & $\begin{array}{l}\text { Service capability } \\
\text { can be stored, } \\
\text { although not the } \\
\text { "end” service if } \\
\text { co-created by the } \\
\text { customer. }\end{array}$ \\
\hline Ownership & $\begin{array}{l}\text { Transfer of } \\
\text { ownership on } \\
\text { purchase }\end{array}$ & $\begin{array}{l}\text { No transfer of } \\
\text { ownership }\end{array}$ & $\begin{array}{l}\text { Complex issue. } \\
\text { Ownership of } \\
\text { object is } \\
\text { transferred, but not } \\
\text { necessarily of } \\
\text { content, depending } \\
\text { on intellectual } \\
\text { property } \\
\text { arrangements. } \\
\text { Generally } \\
\text { ownership of } \\
\text { content is } \\
\text { expanded rather } \\
\text { than transferred } \\
\text { (see body of } \\
\text { paper) }\end{array}$ & $\begin{array}{l}\text { Complex issue } \\
\text { (depends on } \\
\text { intellectual } \\
\text { property } \\
\text { arrangements). } \\
\text { Generally } \\
\text { ownership of } \\
\text { content is } \\
\text { expanded rather } \\
\text { than transferred } \\
\text { (see body of } \\
\text { paper) }\end{array}$ & $\begin{array}{l}\text { No transfer of } \\
\text { ownership of } \\
\text { service but certain } \\
\text { "rights” may be } \\
\text { conferred }\end{array}$ \\
\hline
\end{tabular}

* We have used Grönroos' framework as a point of departure for this table, therefore we also use his vocabulary. Please note that what he refers to as "real value" is the point when value can be realised through sales - i.e. value is expressed from the sellers perspective. One can also argue that real value is only created when the product or service is consumed - i.e. value is expressed from the customers' perspective.

TABLE 1 CONTD. Differences between physical and digital products, services and information products.

This table illustrates the major shift that the Internet, means for the development, management and commercialisation of digital information products and digitally mediated services. Using the dimensions of this table, we can see that physical information products have much in common with physical products as they are constrained by their physical presentation, whereas the characteristics of digital information products are different. In fact, 
in many respects - and in particular if they are interactive - digital information products have more in common with services than with physical information products. Their interactive capability, together with the elimination of the costs and problems associated with physical distribution and the impact of network externalities, open up a multitude of new opportunities for organizations to exploit information through new digital offerings. On the other hand, digitally mediated services have several features in common with traditional products, not present with traditional services available in the physical world. Face-to-face interaction with the customer, so often critical for services in the physical world, is not possible for digitally mediated services. However, service capability can be stored and better controlled, thus promising more consistent quality of services while also removing the constraints of time and place.

This analysis illustrates why the practice of simply moving traditional information products to the Internet will so often fail - physical information products and digital information products have fundamentally different characteristics. In fact, producers of digital information products have more to learn from providers of traditional services than from providers of traditional information products. Worth highlighting is that many on-line services are generally more demanding of the customer than their physical world counterpart. While the customer can be more or less passive in the physical world, he is now required to become more involved in the provision of the service. The service is thus co-created and this has implications for customer value.

As some services move online, significant assumptions are made about the customer, including their knowledge-base. Consider the purchasing of airline tickets. If a customer uses a travel agency in the physical world to purchase a seat, the agent will usually ensure that she understands the travel requirements of the customer and combines that knowledge with her knowledge of airline travel. For example, that a return ticket is cheaper than a single ticket or that a Saturday night stay usually reduces the cost of a ticket. Some travel agents will also book "back-to-back tickets" for midweek travel, which can reduce the cost of tickets - many travellers are unaware of this. Travel websites will usually permit a customer to book single tickets to and from a particular destination; in the physical world, the agent would point out that it is cheaper to buy a return ticket.

Information products, like services in the physical world, are also experience goods (Peterson et al., 1997), that is, the customer has to experience the product in order to value it. How do you know the value of the newspaper until you have read it? Or whether you like a piece of Pre-publication version International Journal of Information Management, Vol 25, 2005, pp. 335-345. 
music until you have listened to it? Or the usefulness of report until you have read it? Therefore consumer choice decisions are influenced by emotional expectations rather than cognitive product attributes. Informational inputs such as critics reviews, word-of-mouth and advertising, as well as latent product interest, are also important determinants of consumer choice (Neelamegham and Jain, 1999). The lack of tangible cues for the customer to assess the quality of the information product of course poses particular problems for their marketing - especially given the emphasis of quality over quantity. A way around this problem is to distribute samples or previews of parts of the information product for free. Building a brand and reputation, which provide some sort of guarantee that the content will have a certain quality or profile, also becomes a critical activity.

Digital information products and digitally mediated services are non-rivalous; that is, one person's consumption does not diminish the amount available to others. Reading a report, for example, does not mean that the information it contains is now not available to others. In fact, any number of people can read the same report at the same time. And, unlike traditional physical assets, it does not depreciate through usage. This is why the issue of transfer of ownership becomes complex, with intellectual property (IP) rights requiring consideration. The seller of an information product still retains the valuable information, no matter how many people it is sold to. However, by becoming widely available its value may reduce; scarcity often means that a higher price can be extracted for particular information. On the other hand, the opposite situation may also hold true, it is only when an information product has become widely known (e.g. a book or a movie), or there is a sufficient number of other compatible information products available on the market, that the information product reaches a critical mass and thus has a greater value to the users (e.g. Napster or MS windows). This is the network effect, and it can be particularly powerful for digital information products because of their ease of distribution (Arthur, 1994).

\section{Conclusion}

In this paper we have suggested that in developing an online strategy, organizations must consider the Internet as a medium and evaluate the implications of this business environment for products and services as well as its impact on consumer behaviour. Taking most existing products and services and moving them directly to the Net without this consideration is likely mean that online strategies are sub-optimal. 
As with any new technology, we are often constrained in our thinking of new applications by the previous technologies that have dominated our society. Over a decade ago, in introducing the concept of reengineering to the world, Hammer (1990) advised against "paving the cow path” with technology - in short, overlaying traditional work processes and practices with technology. He exhorted organizations to seek out innovative opportunities to deploy technologies by redesigning work processes and that this would lead to significant performance improvement. An argument of similar sentiment can be expressed for this medium.

In this paper, we have demonstrated that the nature of products and services changes in virtual environments. The difference between products and services becomes increasingly blurred as products take on characteristics of physical world services and visa versa, and both take on an entirely new set of common characteristics, different from those of the physical world. As the differing characteristics of products and services have guided operations decisions, it is important to now consider the impact of cyberspace on the theory and practice on their design, delivery and management. Given that the new space is defined by information, it may be that in the future the disciplines of operations management and information systems will move closer together.

\section{References}

Arthur, B (1994), Increasing Returns and Path Dependence in the Economy, University of Michigan Press, Ann Arbor.

Bowen, J and Ford, RC (2002), 'Managing service organizations: does having a "thing” make a difference?' Journal of Management, Vol. 28, No. 3, pp. 447-469.

Butler, P and Peppard, J (1998), 'Consumer purchasing on the Internet: processes and prospects', European Management Journal, Vol. 16, No. 5, pp. 600-610.

Butler, P (2003), 'Internet retailing: dislocation, dislocation, dislocation', Working Paper, University of Dublin, Trinity College, Dublin.

Castells, M (2001), The Internet Galaxy: Reflections on the Internet, Business, and Society, Oxford University Press, Oxford.

Datal, S, Landesberg, H. and Zeisser, M. (2000), 'Building digital brands', McKinsey Quarterly, No. 2, pp. 42-51.

Evans, P and Wurster, TS (2000), Blown to Bits: How the New Economics of Information Transform Strategy, Harvard Business School Press, Boston.

Grönroos, C (1990), Service Management, ISL Förlag, Göteborg, Sweden.

Hammer, M (1990), 'Re-engineering work: Don't automate, obliterate', Harvard Business Review, July-August, pp. 104-112.

Havick, J (2000), 'The impact of the Internet on a television-based society', Technology in Society, vol. 22, pp. 273-287. 
Heizer, J. and Render B (1999), Operations Management (Fifth Edition), Prentice-Hall, New Jersey.

Jarvenpaa, S and Grazioli, S (2000), 'Surfing among the sharks: how to gain trust in cyberspace', ed. DA Marchand, TH Davenport and T Dickson, Mastering Information Management, Pearson, London, pp. 197-201.

Koufaris, M and Hampton-Sosa, W (2004) 'The development of initial trust in an online company by new customers’, Information \& Management, Vol. 41, pp. 377-397.

Koufaris, M, Kambil, A and LaBarbera, PA (2002) 'Consumer behavior in web-based commerce: an empirical study', International Journal of Electronic Commerce, Vol. 6, No. 2, pp. 115-138.

Kim, K and Prabhakar, B (2000), 'Initial trust, perceived risk, and the adoption of Internet banking', in Proceedings of $21^{\text {st }}$ International Conference on Information Systems, December 10-13 ${ }^{\text {th }}$, Brisbane, Australia, pp. 537-543.

Lawson, B (2001), The Language of Space, Architectural Press, UK.

McKnight, DH, Choudhury V and Kacmar C (2002) 'The impact of initial consumer trust on intention to transact with a web-site: a trust building model', Journal of Strategic Information Systems, Vol. 11, No. 3/4, pp. 297-324.

Neelamegham, R and Jain, D (1999), 'Consumer choice process for experience goods: an econometric model and analysis’, Journal of Marketing Research, vol. XXXVI, pp. $373-386$

Peterson, R Balasubramanian, S and Bronnenberg, B (1997), 'Exploring the implications of the Internet for Marketing', Journal of the Academy of Marketing Science, Vol. 25, pp. 329-346.

Porter, ME (2001), 'Strategy and the Internet', Harvard Business Review, March, pp. 63-78.

Quinn, JB, Doorley, TL and Paquette, PC (1990), 'Technology in services: rethinking strategic focus', Sloan Management Review, Winter, pp. 79-87.

Reeves, B and Nass, C (1996), The Media Equation: How People Treat Computers, Television and New Media Like Real People and Places, CSLI Publications, Cambridge, USA.

Sampler, J (1998), 'Redefining industry structure for the information age', Strategic Management Journal, vol. 19, pp. 343-355.

Schmenner, RW (1995), Service Operations Management, Prentice-Hall, Englewood Cliffs, New Jersey.

Shapiro, C and Varian, HR (1999), Information Rules: A Strategic Guide to the Network Economy, Harvard Business School Press, Boston, MA.

Slack, N, Chambers, S and Johnson, R (2001), Operations Management, $3^{\text {rd }}$ Edition, Pearson Education Limited, Harlow, England.

Torkzadeh, G and Dhillon, G (2002) 'Measuring factors that influence the success of Internet commerce’, Information Systems Research, Vol. 13, No. 2, pp. 187-204. 